\title{
Seroprevalence of Salmonellosis in Bovine Herds
}

\author{
R. Nethra ${ }^{1 *}$, P. T. Ramesh ${ }^{2}$, B. M. Veeregowda ${ }^{3}$, \\ C. Ansar Kamran ${ }^{1}$, A. Muralidhara ${ }^{4}$ and M. L. Sathyanarayana ${ }^{5}$ \\ ${ }^{1}$ Department of Veterinary Medicine, Veterinary College, Hebbal, Bengaluru, India \\ ${ }^{2}$ Peripheral Veterinary Hospital, Yelahanka, Bengaluru, India \\ ${ }^{3} I A H$ \& VB, Bengaluru, India \\ ${ }^{4}$ Department of VCC, Veterinary College, Hebbal, Bengaluru, India \\ ${ }^{5}$ Department of Veterinary Pathology, Veterinary College, Hebbal, Bengaluru, India \\ *Corresponding author
}

\section{Keywords}

Bovine, Rapid Plate test, Salmonellosis, Seroprevalence

Article Info

Accepted:

07 September 2019

Available Online:

10 October 2019

\section{A B S T R A C T}

Rapid plate test was performed in five different bovine herds at Yenigadale, Ganjigunte, Gowribidanur, Shidlaghata and Chickaballapur classifying animals in the herd into aborted animals, diarrheic animals and apparently healty animals to resolve sero-prevalence of Salmonellosis. The seroprevalence of Salmonellosis was observed to be $42.5 \%$ (17 out of 40 ), $11.5 \%$ (14 out of 122) and 32.8\% (148 out of 451) in aborted animals, diarrhoeic animals and apparently healthy animals respectively from the 613 samples screened. On an overall 29.2\% seroprevalence of Salmonellosis was observed from five herds screened, whereas it was 29.7\%. 30.9\%, 33.3\%, 26.8\% and $19.5 \%$ in the herds at Yenigadale (30/101), Ganjigunte (48/155), Gowribidanur (59/177), Shidlaghata (25/93) and Chickaballapur (17/87), respectively where the seroprevalence reported was increasing with the herd size.

\section{Introduction}

Bovine salmonellosis is of worldwide public health concern and is an economically important disease. Although cattle of all ages can be infected with salmonella bacteria, serious infections and deaths are most often seen in calves of 10 weeks of age (Hume et al., 2004). Dairy cows may serve as asymptomatic carriers of Salmonella.

The potential herd carrier status increases with herd size and Salmonella shedding may be triggered by stresses placed on the animals (Huston et al., 2002). Traditional laboratory culture techniques consume long time before 
getting a positive or negative result, use of simple, rapid serological tests like slide microagglutination test is convenient method for detecting the prevalence of Salmonella in animals (Jonsson, 2013).

In the present study, a rapid plate test was performed to investigate seroprevalence of Salmonellosis in bovines in different herds in karnataka.

\section{Materials and Methods}

The test was performed by mixing serum $(0.02$ $\mathrm{ml})$ with Salmonella Typhimurium somatic antigen $(0.02 \mathrm{ml})$ on a clean slide. The somatic antigen was prepared as per OIE, 2007 by harvesting $S$. Typhimurium on nutrient agar.

The slide was left for 2 minutes, after which the test was read. The test components were stored at $4^{\circ} \mathrm{C}$ and brought to room temperature before being used.

The slide agglutination test was performed for 612 serum samples collected at Yenigadale, Ganjigunte, Gowribidanur, Shidlaghata and Chickaballapur. Amongst these 121 were from diarrhoeic cases and 491 were from nondiarrhoeic apparently healthy animals.

\section{Results and Discussion}

The slide agglutination test was performed for 612 samples collected at Yenigadale, Ganjigunte, Gowribidanur, Shidlaghata and Chickaballapur (Fig. 1). Amongst these, 121 were from diarrheic cases and 491 were from non-diarrheic apparently healthy animals.

The serum samples collected from 121 diarrheic cases were from 32 cattle calves, 20 cattle heifers, 27 lactating cattle, 10 buffalo calves, 14 buffalo heifers and 18 lactating buffaloes. On performing rapid plate agglutination test 18.5 per cent (5 out of 27 ) lactating cattle, 16.6 per cent (3 out of 18) lactating buffaloes, 10 per cent ( 1 out of 10) buffalo calves, 9.3 per cent (3 out of 32) cattle calves, 7.1 per cent (1 out of 14) buffalo heifers and 5 per cent (1 out of 20) cattle heifers were seropositive for Salmonella agglutinins. On an overall 11.6 per cent of diarrheic animals were seropositive for Salmonella agglutinins (Table 1).

The serum samples collected from 491 nondiarrheic cases were from 93 cow calves, 75 cattle heifers, 235 lactating cattle, 17 buffalo calves, 30 buffalo heifers and 41 lactating buffaloes. On performing rapid plate agglutination test 45.9 per cent (108 out of 235) lactating cattle, 34.1 per cent (14 out of 41) lactating buffaloes, 29.4 per cent (5 out of 17) buffalo calves, 25.8 per cent (24 out of 93) cow calves, 10.6 per cent ( 8 out of 75 ) cattle heifers and 10.0 per cent (3 out of 30) buffalo heifers were seropositive for Salmonella agglutinins. Overall 32.9 per cent of nondiarrheic animals were seropositive for Salmonella agglutinins (Table 2).

Association between clinical finding of diarrhoea and presence of Salmonella antibody in serum of animal was determined by using the Chi Square test which was found to be non significant at $5 \%$ level $(\mathrm{P}<0.05)$ in bovine serum.

On an overall 29.2 per cent seroprevalence of Salmonellosis was observed from 613 samples screened, whereas it was 29.7, 30.9, 33.3, 26.8 and 19.5 per cent in the herds at Yenigadale of herd size 101, Ganjigunte of herd size 155, Gowribidanur of herd size 177, Shidlaghata of herd size 93 and Chickaballapur of $\mathrm{f}$ herd size 87 , respectively (Table 3 ) and it was observed to be 42.5 per cent (17 out of 40 ), 11.5 per cent (14 out of 122) and 32.8 per cent (148 out of 451) in aborted animals, diarrheic animals and apparently healthy animals respectively. 
Table.1 Seroprevalence of Salmonellosis in diarrheic bovine by Rapid plate test.

\begin{tabular}{|l|l|l|l|l|}
\hline Animals & Total & Positive & Negative & Positive \% \\
\hline Diarrheic cow calves (<9months age) & 32 & 3 & 29 & 9.3 \\
\hline Diarrheic heifers & 20 & 1 & 19 & 5.0 \\
\hline Diarrheic lactating cattle & 27 & 5 & 22 & 18.5 \\
\hline Diarrheic Buffalo calves & 10 & 1 & 9 & 10.0 \\
\hline Diarrheic heifers & 14 & 1 & 13 & 7.1 \\
\hline Diarrheic adult buffalo & 18 & 3 & 15 & 16.6 \\
\hline & 121 & 14 & 107 & 11.6 \\
\hline
\end{tabular}

Table.2 Seroprevalence of Salmonellosis in non diarrheic bovine by Rapid plate test.

\begin{tabular}{|l|l|l|l|l|}
\hline Animals & Total & Positive & Negative & Positive \% \\
\hline Non diarrheic cow calves (< 9months age) & 93 & 24 & 69 & 25.8 \\
\hline Non diarrheic heifers & 75 & 8 & 67 & 10.6 \\
\hline Non diarrheic lactating cattle & 235 & 108 & 127 & 45.9 \\
\hline Non diarrheic Buffalo calves. (<9months age) & 17 & 5 & 12 & 29.4 \\
\hline Non diarrheic heifers & 30 & 3 & 27 & 10.0 \\
\hline Non diarrheic adult buffalo & 41 & 14 & 27 & 34.1 \\
\hline & 491 & 162 & 329 & 32.9 \\
\hline
\end{tabular}

Fig.1 Serum samples showing positive reaction for the slide agglutination test performed using whole cell antigen of Salmonella Typhimurium serotype.

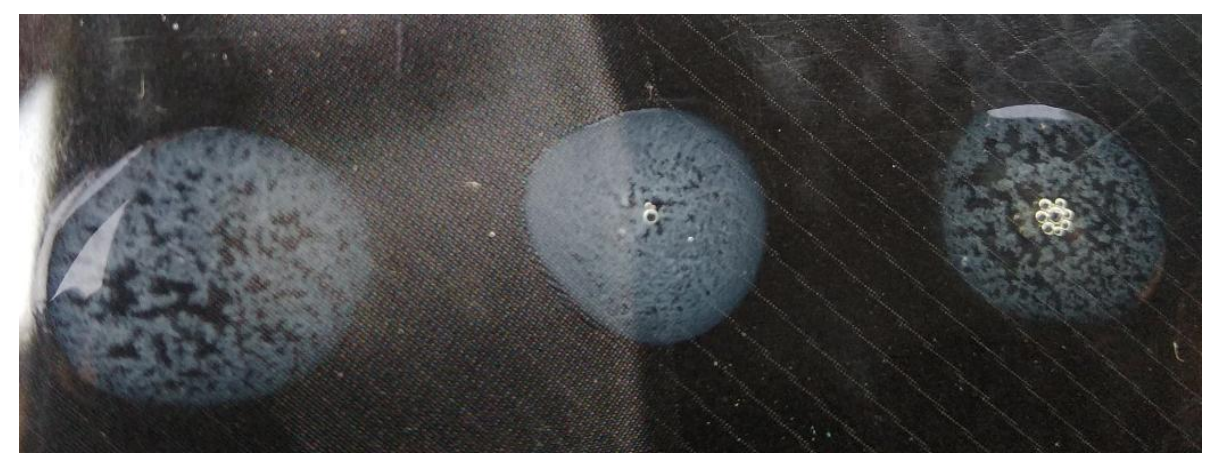

Grading of agglutination reaction:

433 serum samples showed no agglutination - Negative

30 serum samples showed barely visible, very small / small agglutinates, opaque background - + 58 serum samples showed many small agglutinates background not completely clear - ++ 97 serum samples showed several large agglutinates - +++ 
Table.3 Herd wise seroprevalence of Salmonellosis

\begin{tabular}{|c|c|c|c|c|c|c|c|c|c|c|c|c|}
\hline \multirow[t]{2}{*}{ Herd } & \multicolumn{3}{|c|}{ Aborted } & \multicolumn{3}{|c|}{ Diarrheic } & \multicolumn{3}{|c|}{ Apparently healthy } & \multicolumn{3}{|c|}{ Total animals } \\
\hline & $\begin{array}{l}\text { No. of } \\
\text { animals }\end{array}$ & Positive & $\begin{array}{l}\text { Prevalence } \\
(\%)\end{array}$ & $\begin{array}{l}\text { No. of } \\
\text { animals }\end{array}$ & Positive & $\begin{array}{l}\text { Prevalence } \\
(\%)\end{array}$ & $\begin{array}{l}\text { No. of } \\
\text { animals }\end{array}$ & Positive & $\begin{array}{l}\text { Prevalence } \\
(\%)\end{array}$ & $\begin{array}{l}\text { No. of } \\
\text { animals }\end{array}$ & Positive & $\begin{array}{l}\text { Prevalence } \\
(\%)\end{array}$ \\
\hline Yenigadale & 4 & 1 & 25.0 & 21 & 1 & 4.7 & 76 & 28 & 36.8 & 101 & 30 & 29.7 \\
\hline Ganjigunte & 12 & 5 & 33.3 & 29 & 4 & 13.7 & 114 & 39 & 34.2 & 155 & 48 & 30.9 \\
\hline Shidlaghata & 7 & 3 & 42.8 & 20 & 1 & 5.0 & 66 & 21 & 31.8 & 93 & 25 & 26.8 \\
\hline Chickaballapur & 4 & 1 & 25.0 & 15 & 1 & 6.2 & 67 & 15 & 22.3 & 86 & 17 & 19.5 \\
\hline Total & 40 & 17 & 42.5 & 121 & 14 & 11.5 & 451 & 148 & 32.8 & 612 & 179 & 29.2 \\
\hline
\end{tabular}


In the present study, the observed seroprevalence of Salmonellosis from five bovine herds $(29.2 \%)$ was in accordance with Jonsson (2013) and Wolff et al., (2017). The detection of Salmonella antibodies in large number of healthy and sick animals is not surprising because salmonellosis is hyperendemic in India.

Maximal seroprevalence was detected in adult cattle $(18.5 \%)$ followed by adult buffalo (16.6\%) among diarrhoeic animals. Seroprevalence was also detected to be maximum in non diarrhoeic adult cattle (45.9\%). The results were in accordance with Singh et al., (2009) and Upadhyay et al., (2014).

In our study an appreciably high seroprevalence was observed in adult animals as compared to calves. The results observed were in accordance with Upadhyay et al., (2014). In agreement to our findings, Verma et al., (2008) have also reported high seroprevalence of Salmonella agglutinins in dogs with the increasing age, which might be either due to increase in susceptibility of dogs with age as in humans or repeated subclinical infection which increased the antibodies detected by the test. Adult cows and buffaloes are more susceptible as compared to young ones.

On an overall the seroprevalence of Salmonellosis was $42.5 \%$ in aborted animals, $11.5 \%$ in diarrhoeic animals and $32.8 \%$ in apparently healthy animals. The findings indicated that the occurrence of diarrhoea and Salmonella antibody in serum are not associated with each other. Diarrhoea in young calves has a multifactorial etiology and may be caused by rota virus, corona virus, Escherichia coli, or Salmonella spp. Screening of available literature did not reveal any study conducted on sero prevalence of Salmonella agglutinin in bovine diarrhoeic animals of Karnataka.
In the present study, the reported seroprevalence increased with the herd size. This observation is in accordance with Huston et al., (2002). Large herds may have more intensive management practices, may introduce more cows, and be more likely to experience stress attributable to animal mixing, crowding, and transportation, compared with smaller herds; however, the biological mechanism for this increased risk is unknown. Because infected cows shed the organism intermittently, the probability of obtaining a positive test result increases proportionally to the number of cows tested.

The seroprevalence of salmonellosis in bovines in Karnataka was found to be high which is of zoonotic importance and this may also be a reason in the lower production in the dairy industry.

\section{References}

Hume, M.E., Edrington, T.S., Looper, M.L., Callaway, T.R., Genovese, K.J. And Nisbet, D.J., 2004. Salmonella genotype diversity in nonlactating and lactating dairy cows. J. Food Prot. 67(10): 2280-2283.

Huston, C.L., Wittum, T.E., Love, B.C. And Keen, J.E., 2002. Prevalence of fecal shedding of Salmonella spp in dairy herds. JAVMA. 220(5): 645-649.

Jönsson, E., 2013. Seroprevalence and risk factors for bovine brucellosis, salmonellosis and bovine viral diarrhea in urban and peri-urban areas of Kampala, Uganda. Thesis., Upssala.

Lanzas, C., Warnick, L.D., Ivanek, R., Ayscue, P., Nydam, D.V. and Grohn, Y.T., 2008. Vet. Res. 39: 58-61.

Office International of Epizootic, 2016. Salmonellosis. Chapter 2.9.8. Terrestrial Manual, pp: 1-18.

Sachan, N., Nautiyal, B., Agarwal, R.K., Singh, V.P. and Verma, A.K., 2013. 
Sero-epidemiological Pattern of Salmonellosis in Animals of Rohilkhand Region, Uttar Pradesh, India. J. Anim. Healt. and Prod.1(1): 6-9.

Singh, B. R., J. C. Verma, K. P. Singh and Y. P. Singh., 2009. Sero-prevalence of Salmonella infection in animals in north India. Haryana Vet. 48: 43-46.

Upadhyay, A. K., Swamy, M., Dubey,A. and
Shrivastava, D. P., 2014. Prevalence of bovine salmonellosis in organized dairy farms. Indian J. Vet Sci. Biotechnol., 10(3): 60-62.

Verma, A.K., Sinha, D.K. and Singh, B.R., 2008. Micro-Agglutination Test (MAT) based sero-epidemiological study of salmonellosis in dogs. $J$. Immunol. and Immunopathology, 10(1): 29-35.

\section{How to cite this article:}

Nethra, R., P. T. Ramesh, B. M. Veeregowda, C. Ansar Kamran, A. Muralidhara and Sathyanarayana, M. L. 2019. Seroprevalence of Salmonellosis in Bovine Herds. Int.J.Curr.Microbiol.App.Sci. 8(10): 473-478. doi: https://doi.org/10.20546/ijcmas.2019.810.051 